LINGUODIDACTICA XX

DOI: 10.15290/lingdid.2016.20.15

\author{
dr Eugenia Maksimowicz \\ Uniwersytet w Białymstoku \\ Wydział Filologiczny, Instytut Filologii Wschodniosłowiańskiej \\ tel. 857457450 \\ e-mail: maximovitch@interia.pl
}

\title{
ОБ ИСПОЛЬЗОВАНИИ БИБЛЕЙСКИХ ФРАЗЕОЛОГИЗМОВ В РАЗГОВОРНОМ СТИЛЕ СОВРЕМЕННОГО РУССКОГО ЯЗЫКА
}

\author{
STRESZCZENIE \\ Wykorzystanie frazeologizmów biblijnych w odmianie potocznej \\ współczesnego języka rosyjskiego
}

\begin{abstract}
Frazeologizmy biblijne często przenikają do naszego języka, wnosząc wzniosłą duchowość i wartość pouczającą. Liczne wyrażenia i cytaty zaczerpnięte z Biblii, utrwalone w postaci znanych powiedzeń, sentencji, używane są powszechnie w języku codziennym. Frazeologizmy pochodzenia biblijnego funkcjonują też w stylu potocznym języka, zarówno w jego różnorodnych formach ustnych, jak i pisemnych, np. w wypowiedziach dialogowych w tekstach literackich oraz publicystycznych, uczestnicząc w procesie charakteryzowania postaci literackich jako językowy środek stylistyczny.
\end{abstract}

Słowa kluczowe: styl potoczny, ustna odmiana języka, frazeologizmy biblijne, literatura piękna

\section{SUMMARY}

The use of biblical idioms in colloquial variety of modern Russian language

Biblical idioms quite often penetrate into our language, bringing the sublime spirituality and informative value. Numerous phrases and quotations taken from the Bible, fixed in the form of well-known sayings, maxims, are commonly used in everyday language. Idioms of biblical origin also function in the colloquial style of language, both in its various oral and written forms, for example, in the dialog statements in literary and journalistic texts, participating in the process of characterization of literary figures as a stylistic medium.

Key words: colloquial style, oral variety of language, biblical idioms, belles-lettre 
Разговорный стиль, обладая в большей степени, чем другие стили, своеобразием языковых средств, выходящих за пределы кодифицированного литературного языка, занимает особое место в системе современных функциональных стилей. Разговорный стиль - это, прежде всего, стиль нашего повседневного общения. Традиционно его принято характеризовать как стиль диалога и стиль устной речи, хотя он используется и в письме - в личной переписке и в личных дневниках. Более того, с развитием интернета (в частности, с появлением блогов, социальных сетей, форумов) стало очевидно, что разговорный стиль является стилем письма ничуть не в меньшей мере, чем стили книжные. Как бы то ни было, говорим ли мы об устной или письменной речи, основная функция разговорного стиля - это общение. Он всегда используется в неофициальной обстановке, и говорящие непосредственно участвуют в коммуникации. Следовательно, разговорному стилю присущи спонтанность, непринуждённость, отсутствие чёткой структуры и логики изложения, перестройка речи на ходу, терпимость собеседников в отношении ошибок, эмоциональность.

Под разговорным стилем понимают особенности и колорит устноразговорной речи носителей литературного языка ${ }^{1}$. Отражение устного общения в письменных текстах (в диалогах художественной литературы или публицистики, в рекламных текстах) является имитацией такого общения, стилизацией разговорной речи средствами письменной речи ${ }^{2}$.

Общими экстралингвистическими признаками, обусловливающими формирование разговорного стиля, являются неофициальность и непринужденность общения; непосредственное участие говорящих в разговоре; неподготовленность речи, ее автоматизм; преобладающая устная форма общения, при этом обычно диалогическая (хотя возможен и устный монолог). Обычной областью такого общения является бытовая, обиходная сфера.

В качестве наиболее общих специфических стилевых черт разговорного стиля речи выделяются непринужденный и даже фамильярный характер речи, эллиптичность средств выражения на всех языковых уровнях, конкретизированный (а не понятийный) характер речи, прерывистость и непоследовательность ее с логической точки зрения, эмоционально-оценочная

1 М.Н. Кожина, Стилистика русского языка: учебник для студентов пед. институтов по спец. «Рсский язык и литература», Москва 1993, s. 213.

2 Г.Я. Солганик, Т.С. Дроняева, Стилистика современного русского языка и культура речи, Москва 2005, s. 57. 
информативность и аффективность. К типичным (но не специфичным) стилевым чертам разговорной речи относятся идиоматичность и известная стандартизованность, личностный характер речи. Все это находит яркое и последовательное отражение в составе употребляемых в этой сфере языковых единиц и особенностях их функционирования.

Библейская фразеология активно функционирует в речи, проникая во все сферы общения, в том числе и в разговорную. Библейские фразеологизмы часто присутствуют в нашей речи, привнося в нее высокую духовность и поучительный оттенок. Библия - самая популярная книга человечества, многократно читаемая и повторяемая на церковных службах, на семейных чтениях. Не удивительно, что многие высказывания и цитаты стали крылатыми и часто употребляются в повседневной речи.

Большинство фразеологизмов библейского происхождения, зафиксированных в разговорном стиле, носит нейтральный характер (всему свое время, зарыть (зарывать) талант (в землю), козел отпущения, манна небесная, не от мира сего, стереть (исчезнуть, пропасть) с лииа земли). Так, в контексте устной разговорной речи " - Ждешь его возвращения как манны небесной» [высказывание незнакомца в московском метро] выявлен пример употребления фразеологизма библейского происхождения манна небесная со значением «Что-либо желанное, крайне необходимое, редкое» ${ }^{3}$, возникшего на основе библейского сюжета, описанного в книге Исход. Манна - пища, которую Бог посылал иудейскому народу каждое утро с неба, когда «сыны Израиля» шли пустыней в страну обетованную [Исход, 16: 14-16, 31]. Еще один фразеологизм библейского происхождения не от мира сего со значением «О крайне не приспособленном к жизни человеке, о мечтателе, фантазере; о странном, наивном, доверчивом человеке» ${ }^{4}$, имеющий основой текст Евангелия от Иоанна: «Царство мое не от мира сего» [Иоанн, 18: 36], используется в контексте: «- У меня соседка такая странная, как ... не от мира сего...» [высказывание двоюродной сестры автора].

В диалогических единствах в текстах художественной литературы функционируют фразеологизмы библейского происхождения (зарывать талант в землю, козел отпущения). См.: фразеологизм зарывать талант в землю со значением «Губить свои способности, не использовать их, не давать им развиться» ${ }^{5}$, восходящий к тексту Нового Завета: «Получивший же один талант пошел и закопал его в землю и скрыл серебро господина

Л.Г. Кочедыков, Краткий словарь библейских фразеологизмов, Самара 2006, s. 97.

4 А.К. Бирих, В.М. Мокиенко, Л.И. Степанова, Словарь русской фразеологии. Историко-этимологический справочник, Санкт-Петербург 1998, s. 380.

5 А.И. Молотков, Фразеологический словарь русского языка, Москва 1986, s. 170. 
своего» [Матфей, 25: 18], выявлен в контексте: «- Но у тебя талант, Егор! Ть не имеешь права зарывать его в землю!» [Маринина 2005: 40]. Другой фразеологизм библейского происхождения козел отпущения со значением «Человек, на которого постоянно сваливают чужую вину, несущий ответственность за других» ${ }^{6}$, используется в контексте: «- Не знаю, кто придумал махинацию с квартирой, но козла отпущения выбрали правильно - простоватого Романа Виноградова» [Донцова 2007a: 311]. Источником данного фразеологизма послужил существовавший у древних евреев обряд: в день грехоотпущения первосвященник возлагал обе руки на голову живого козла в знак возложения на него всех грехов еврейского народа, после чего козел изгонялся в пустыню [Левит, 16: 21-22].

В публицистических текстах в жанре интервью выявлены примеры употребления фразеологизмов библейского происхождения стереть (ucчезнуть, пропасть) с лииа земли, нет (несть) пророка в своем отечестве. Фразеологизм библейского происхождения стереть (исчезнуть, пропасть) с лииа земли со значением «Полностью уничтожить что-либо, разрушить до основания (подвергнуться уничтожению, истреблению)» ${ }^{7}$, восходящий к сказанию из Ветхого Завета о Каине: «Вот, Ты теперь сгоняешь меня с лица земли, и от лица Твоего я скроюсь, и буду изгнанником и скитальцем на земле; и всякий, кто встретиться со мной, убьет меня» [Бытие, 4: 14], используется в контексте: «- Мой дед прошел всю войну, а теперь памятник, посвященный героям Великой Отечественной, сотрут с лииа земли!» - возмущается Александра Кузнеизова» [Аргументы и Факты 2006: 19]. Фразеологизм библейского происхождения нет (несть) пророка в своем отечестве со значением «Заслуги своих близких, соотечественников, часто не ценят, отдавая предпочтение авторитетам со стороны», имеющий основой евангельские тексты [Матфей, 13: 57; Марк, 6: 4; Лука, 4: 24; Иоанн, 4: 44]: «И сказал: истинно говорю вам: никакой пророк не принимается в своем отечестве» [Лука, 4: 24], используется в контексте: «- Нет пророка в моем отечестве. Иисус Христос, Моисей, Магомет. Вот трое парнишек, которые мне интереснь» (из интервью с Б. Грачевским, основателем тележурнала «Ералаш») [Телесемь 2009: 4]. В данном случае окружающий контекст, наличие разговорной лексики (парнишка - разг. «мальчик, подросток» ${ }^{9}$ ) способствуют созданию комического эффекта.

Л.Г. Кочедыков, Краткий словарь..., ор. cit., s. 88.

Ibidem, s. 155.

А.К. Бирих, В.М. Мокиенко, Л.И. Степанова, Словарь русской фразеологии..., ор. cit., s. 475.

9 С.И. Ожегов, Н.Ю. Шведова, Толковый словарь русского языка, Москва 1999, s. 493. 
Часть фразеологизмов библейского происхождения, употребляемых в разговорном стиле, имеет книжный характер (вавилонская башня, возвращзаться (возвратиться) на круги своя, метать бисер перед свиньями, нести (принять) свой крест). Однако книжные фразеологизмы библейского происхождения не доминируют в разговорном стиле, в отличие от других стилей (научного, публицистического, стиля художественной литературы). В устной разговорной речи зафиксировано употребление фразеологизма библейского происхождения метать бисер перед свиньями со значением книжн. «Говорить, объяснять что-либо тому (тем), кто не может понять и по достоинству оценить этого» ${ }^{10}$, восходящего к тексту Евангелия от Матфея: «Не давайте святыни псам и не бросайте жемчуга вашего перед свиньями, чтобы они не попрали его ногами своими и, обратившись, не растерзали вас» [Матфей, 7: 6].См.: в контексте: « - Ть же знаешь, что говорить ему об этом бесполезно. Нечего метать бисер перед свиньями!» [О. Будько, 45 лет].

В художественных текстах, чаще всего в диалогах, активно функционируют книжные фразеологизмы библейского происхождения. Во фразеологизме библейского происхождения вавилонская башня со значением книжн. «Об очень высоком строении»" башню нельзя увидеть, - ответил сирруб» [Пелевин 2004: 186] отражен библейский сюжет о сооружении людьми в Древнем Вавилоне башни (столпа), описанный в книге Ветхого Завета Бытие [Бытие, 11]. Другой фразеологизм библейского происхождения возвращзаться (возвратиться) на круги своя со значением книжн. «Вернуться к прежнему положению, состоянию» ${ }^{12}$, восходящий к книге Екклесиаст Ветхого Завета: «Идет ветер к югу, и переходит к северу, кружится на ходу своем, и возвращается на круги своя» [Екклесиаст, 1: 6], используется в контексте: «- Все возвращ,ается на круги своя, - продолжал Устрелов, - ангел революиии тихо отлетает от страны» [Аксенов 2006: 6]. Фразеологизм библейского происхождения нести (принять) свой крест со значением книжн. высок. «Терпеливо переносить страдания, невзгоды, мириться со своей печальной участью» ${ }^{13}$, например, в контексте: « - Ладно, я несла этот крест и поташу его дальше» [Донцова 20076: 91] восходит к Новому Завету Библии: «И кто не несет креста своего и идет за Мною, не может быть моим учеником» [Лука, 14: 27].

10 А.К. Бирих, В.М. Мокиенко, Л.И. Степанова, Словарь русской фразеологии..., op. cit., s. 47.

11 Л.Г. Кочедыков, Краткий словарь..., s. 27.

12 Ibidem, s. 37.

13 А.К. Бирих, В.М. Мокиенко, Л.И. Степанова, Словарь русской фразеологии..., ор. cit., s. 315. 
Пародийное использование в художественном контексте книжного высокого фразеологизма нести (принять) свой крест в сочетании с разговорными лексическими средствами (ладно, потащу) создает яркий стилистический эффект.

Большая часть фразеологизмов библейского происхождения не утратила связи с первоисточником - Библией - и носит книжный характер. Однако постоянное употребление данных единиц в речи «стирает» в ряде случаев присущую им изначальную книжность, в результате чего происходит постепенный стилистический переход фразеологизма библейского происхождения из книжного в нейтральный, а затем, ввиду частого употребления в обиходной речи, в разговорный. Данный процесс подтверждается проведенным анализом современных фразеологических словарей. Так, в «Историко-этимологическом словаре русской фразеологии» (1998) А.К. Бирих, В.М. Мокиенко, Л.И. Степановой фразеологизмы библейского происхождения с пометой разговорные отсутствуют. В «Кратком словаре библейских фразеологизмов» (2006) Л.Г. Кочедыкова с пометой разговорные даются некоторые фразеологизмы: всякой твари по паре, живого (целого) места нет, из одной глины (вылеплень), крошки (крохи) с барского стола (собирать, получать), на ветер говорить (слова бросать), с (от) головы до ног (пят), стыд и срам, убей меня Бог, хромать на оба колена (обе ноги). В «Школьном фразеологическом словаре русского языка» В.П. Жукова, А.В. Жукова (1989) с пометой разговорные даются следующие фразеологизмы библейского происхождения: живого места нет (не осталось), беречь (хранить) как зенииу ока, как небо и земля, как осиновый лист дрожать (задрожать, трястись, затрястись), капля в море, между небом и землей, наобум Лазаря, петь (запеть) Лазарем, язык прилип к гортани. В «Словаре русской фразеологии» (2008) Е.А. Быстровой пометой разговорные обозначены следующие фразеологизмы библейского происхождения: капля в море, пройти сквозь огонь и воду и медные трубы, Фома неверный, а также указывается на принадлежность к разговорному стилю всех фразеологизмов с компонентом Бог: Бог весть, Бог его знает, Бог, Боже ты мой!, Бог с тобой, с ним, с ней, с вами, с ними.

В разговорном стиле фразеологизмы библейского происхождения, имеющие разговорную окраску, достаточно продуктивны (хромать на оба колена (обе ноги), живого (целого) места нет, с (от) головы до ног (nят)). Наибольшее количество примеров употребления разговорных фразеологизмов библейского происхождения отмечено в устной разговорной речи. См.: фразеологизм библейского происхождения хромать на оба колена (обе ноги) со значением разг. «О чем-либо, о ком-либо, находящемся в очень 
плохом состоянии» ${ }^{14}$, восходящий к тексту Ветхого Завета: «И подошел Илия ко всему народу, и сказал: долго ли вам хромать на оба колена?» [Третья Книга Царств, 18: 21], зафиксирован в контексте: «- Пусть учит! ЕГЭ напишет, значит поступит. Я пока результатов не вижу, по крайней мере, математика у него хромает на обе ноги» [В.Н. Зеленова, 63 г.]. Другой фразеологизм библейского происхождения из одной глины (вылеплены) со значением разг. ирон. «Того же происхождения; о сходных в каком-либо отношении людях» ${ }^{15}$, например, в контексте: «- Такой же, как брат... Жадныцй да вредный, из одной глины вылеплены с братцем, чего удивляться-то!» [П.С. Прохорова, 82 г.] восходит к тексту Ветхого Завета, повествующему о том, что Бог вылепил первых людей из глины [Бытие, 2: 7].

В диалогах художественных текстов выявлены примеры активного употребления разговорных фразеологизмов библейского происхождения. См.: фразеологизм библейского происхождения живого (целого) места нет со значением разг. «Нет цельного, здорового, нетронутого» ${ }^{16}$ выявлен в контексте: « - И жену свою потеряет! Всю брюликами обвесил, живого места не оставил!» [Донцова 2005: 12]. Фразеологизм возник на основе книги Псалтыри: «Нет целого места в плоти моей от гнева Твоего» [Псалтырь, 37: 4]. Фразеологизм библейского происхождения $c(\mathrm{om})$ головы до ног (nяm) со значением разг. «Целиком, полностью, сплошь; во всех отношениях, во всем» ${ }^{17}$, восходящий к тексту Ветхого Завета: «Поразит тебя Господь от подошвы ноги твоей до самого темени головы твоей» [Второзаконие, 28: 35], реализуется в контексте: «- Ты где это шатаешься? - настороженно поинтересовался он. - Пришла домой в десятом часу, мокрая с головы до ног... как понимать это прикажешь?» [Токарева 2007: 321].

Частое употребление находят в разговорном стиле фразеологические единицы с компонентом Бог (Господь, Христос). См.: фразеологическая единица не дай Бог со значением разг. «Вернуться к прежнему положению, состоянию» ${ }^{18}$, например, в контексте: «Когда мы с Кабалье стояли на сиене Кремля и мне вручили этот сертификат, она сказала: «Не дай Бог тебе им воспользоваться» (из интервью с певцом Н. Басковым) [Аргументы и Факты 2008: 30]; фразеологическая единица Бог с тобой (с ним, с ней, с ними, с вами) со значением разг. «Как можно, зачем? (выражение несогласия,

\footnotetext{
14 Л.Г. Кочедыков, Краткий словарь..., op. cit., s. 168.

15 Ibidem, s. 76.

16 Ibidem, s. 63.

17 Ibidem, s. 146.

18 Ibidem, s. 37.
} 
упрека, удивления, недовольства и т. п.)» ${ }^{19}$, например, в контексте: «- Значит, все-таки нашелся мужчина, который сумел влюбить ее в себя? - Да Бог с вами, надо знать Аниту, чтобы все понимать так, как оно есть на самом деле! - рассмеялся Волков» [Маринина 2005: 331]; фразеологическая единица Ради Бога со значением разг. «Пожалуйста (при усиленной просьбе)» ${ }^{20}$, например, в контексте: «- Никогда себе не прошу... - приговаривала себя Александра. - Перестань, ради Бога, мама! Вот уж этого на себя не бери. Вот уж это точно мое... - плакала Ника» [Улицкая 2008: 562].

Таким образом, фразеологизмы библейского происхождения активно функционируют в разговорном стиле как в устной разговорной речи, так и в диалогических единствах в текстах художественной литературы и публицистики, выступая в качестве средства языковой характеристики персонажей. Доминирующую роль выполняют нейтральные фразеологизмы (всему свое время, зарывать талант в землю, козел отпущения, манна небесная, не от мира сего, стереть (исчезнуть, пропасть) с лииа земли). Продуктивными являются разговорные фразеологизмы библейского происхождения (живого (целого) места нет, из одной глины (вылеплены), с (от) головы до ног (nят), хромать на оба колена (обе ноги)). В большом количестве в разговорном стиле представлены фразеологические единицы с компонентом Бог (Бог с тобой (с ним, с ней, с ними, с вами), не дай Бог, ради Бога). Книжные фразеологизмы библейского происхождения характеризуются низкой степенью продуктивности в разговорном стиле и используются в диалогических единствах художественных и публицистических текстов в сочетании с иностилевыми лексико-фразеологическими средствами для создания стилистического эффекта (вавилонская башня, возвращаться (возвратиться) на круги своя, метать бисер перед свиньями, нести (принять) свой крест). Некоторые книжные и разговорные фразеологизмы библейского происхождения, зафиксированные в разговорном стиле, имеют эмоциональноэкспрессивную окраску (нести (принять) свой крест (книжн. высок.), из одной глинь (вылеплены) (разг. ирон.).

19 Е.А. Быстрова, А.П. Окунева, Н.М. Шанский, Фразеологический словарь русского языка: около 1000 единии, Москва 2008, s. 32.

20 А.Н. Тихонов, А.Г. Ломов, Л.А. Ломова, Фразеологический словарь современного русского литературного языка, Москва 2003, s. 19. 


\section{Библиография}

Кожина М.Н., Стилистика русского языка: учебник для студентов пед. институтов по спеи. «Русский язык и литература» 1993.

Солганик Г.Я., Дроняева Т.С., Стилистика современного русского языка и культура речи, Москва 2005.

\section{Словари и справочники}

Бирих А.К., Мокиенко В.М., Степанова Л.И., Словарь русской фразеологии. Историко-этимологический справочник, Санкт-Петербург 1998.

Быстрова Е.А., Окунева А.П., Шанский Н.М., Фразеологический словарь русского языка: около 1000 единии, Москва 2008.

Жуков В.П., Жуков А.В., Школьный фразеологический словарь русского языка: пособие для учашзихся. - 2-е изд., переработанное, Москва 2009.

Кочедыков Л.Г., Краткий словарь библейских фразеологизмов, Самара 2006.

Молотков А.И., Фразеологический словарь русского языка, Москва 1986.

Ожегов С.И., Шведова Н.Ю., Толковый словарь русского языка, Москва 1999.

Тихонов А.Н., Ломов А.Г., Ломова Л.А., Фразеологический словарь современного русского литературного языка, Москва 2003.

\section{Список источников языкового материала}

Аксенов В.П., Московская сага. Война и тюрьма, Москва 2006.

Донцова Д.А., Эта горькая сладкая месть, Москва 2007а.

Донцова Д.А., Верхом на «Титанике», Москва 20076.

Донцова Д.А., Грапия с пропеллером, Москва 2005.

Маринина А.Б., Закон трех отриизаний, Москва 2005.

Маринина А.Б., Замена объекта, Москва 2005.

Пелевин В.О., Generation «П», Москва 2004.

Токарева В.С., Неромантичный человек, Москва 2007.

Улицкая Л.Е., Медея и ее дети, Москва 2008.

\section{Периодические издания}

„Аргументы и Факты” 2006, № 29.

„Аргументы и Факты” 2008, № 42.

„Телесемь” 2009, № 42. 